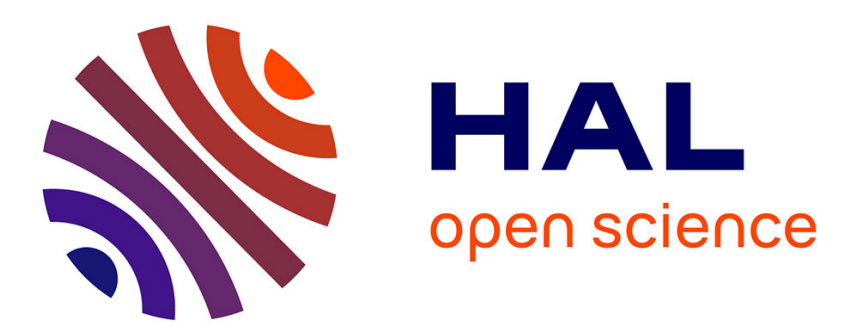

\title{
Anisotropy beneath the Pyrenees Range from teleseismic shear wave splitting: Results from a test experiment
}

Guilhem Barruol, Annie Souriau

\section{To cite this version:}

Guilhem Barruol, Annie Souriau. Anisotropy beneath the Pyrenees Range from teleseismic shear wave splitting: Results from a test experiment. Geophysical Research Letters, 1995, 22 (4), pp.493-496. 10.1029/94GL03225 . hal-01389118

\section{HAL Id: hal-01389118 \\ https://hal.univ-reunion.fr/hal-01389118}

Submitted on 28 Oct 2016

HAL is a multi-disciplinary open access archive for the deposit and dissemination of scientific research documents, whether they are published or not. The documents may come from teaching and research institutions in France or abroad, or from public or private research centers.
L'archive ouverte pluridisciplinaire HAL, est destinée au dépôt et à la diffusion de documents scientifiques de niveau recherche, publiés ou non, émanant des établissements d'enseignement et de recherche français ou étrangers, des laboratoires publics ou privés. 


\title{
Anisotropy beneath the Pyrenees range from teleseismic shear wave splitting: results from a test experiment
}

\author{
Guilhem Barruol \\ Laboratoire de Tectonophysique, URA 1364, Univ. Montpellier II, France.
}

\author{
Annie Souriau \\ OMP / GRGS, Toulouse, France.
}

\begin{abstract}
We have investigated the seismic anisotropy from SKS and SKKS wave splitting along a $\mathrm{N}-\mathrm{S}$ profile perpendicular to the Pyrenean mountain belt. The line crossed the North Pyrenean Fault (NPF), which probably represents the plate boundary between the European and the Iberian plates. We observed large delay times $\delta t(1.3$ to $1.5 \mathrm{~s})$ and uniform fast polarization directions $\phi(\mathrm{N} 100 \mathrm{E})$ at three stations located on the Iberian plate. On the other hand, $\delta t$ are smaller $(0.5-1.0 \mathrm{~s})$ and the $\phi$ scattercd at stations located north of the NPF. The small scale variability, the relation with surface geology and the correlation of the $\delta \mathrm{t}$ with lithospheric thickness suggest that the anisotropy could be predominantly of lithospheric origin. However, an asthenospheric contribution cannot be ruled out. In the North Pyrenean Zone, an important thermal event before the Pyrenean compression häs likely erased the former mantle fabric. The observed anisotropy is then likely related to the Pyrenean orogeny. On the Iberian plate, our splitting parameters are similar to those obtained at two stations located on Hercynian structures in Central Spain. This suggests that two contributions are likely superposed to that of the Pyrenean built up: one related to the Hercynian orogeny and the other one related to the rotation of the Iberian plate.
\end{abstract}

\section{Introduction}

A key point in the understanding of plate tectonics is the geometry of mantle flow at plate boundaries. Recent seismological developments provide a way to obtain informations on upper mantle anisotropy beneath a seismic station using shear wave splitting [e.g., Silver and Chan, 1988]. The anisotropy in the upper mantle is mainly controlled by mineral lattice preferred orientations, particularly that of olivine, the primary upper mantle mineral [e.g., Nicolas and Christensen, 1987]. Splitting of teleseismic shear waves may be therefore related to the mantle deformation, and enables one to study its behavior in tectonic areas. In the present study, we investigate the anisotropy beneath the Pyrenees from splitting of SKS and SKKS waves.

The Pyrenees derive from the continental collision between Iberia and Europe. The orogeny began with an extensive episode related to the opening of the Bay of Biscay during the lower Cretaceous [see review by Choukroune, 1992]. This episode has been ascribed either to a large sinistral rotation of Iberia with respect to Eurasia, or to a scissors opening of the Bay of Biscay.

\section{Copyright 1995 by the American Geophysical Union.}

Paper number 94GL03225

0094-8534/95/94GL-03225\$03.00

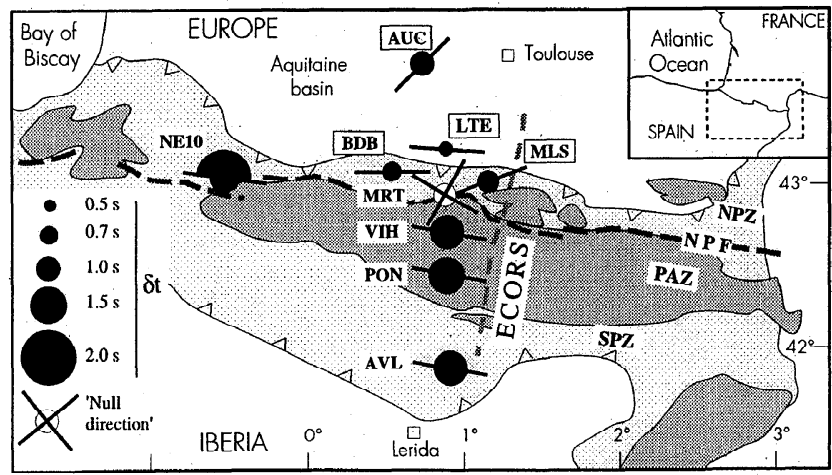

Figure 1: Map of the splitting results. Circle sizes are proportional to the delay times $\delta \mathrm{t}$. Fast polarizations $\phi$ are indicated by black lines. A null direction corresponds either to the fast or slow anisotropic direction or to the absence of anisotropy. NPZ: North Pyrenean Zone, PAZ: Pyrenean Axial Zone, SPZ: South Pyrenean Zone. The North Pyrenean Fault (NPF) is considered to be the boundary between European and Iberian plates. The ECORS profile and the measurements obtained at NE10 [Souriau and Njike-Kassala, 1993] are also shown.

It was followed by a N-S compression in Late Cretaceous and during Tertiary times. The belt is divided in several E-W oriented units (Fig. 1): the central part of the belt (the Pyrenean Axial Zone, PAZ) is formed by Hercynian material free of any pervasive Pyrenean deformation. The South Pyrenean Zone (SPZ) comprises sedimentary nappes that overthrust the Ebro basin southwards. The North Pyreinean Zone (NPZ), formed by Mesozoic material, Hercynian massifs and upper mantle slices, was thrust northwards over the Aquitaine basin. The North Pyrenean Fault (NPF) is a major vertical discontinuity that runs $\mathrm{E}-\mathrm{W}$ along the belt. It separates the NPZ from the PAZ and is considered to be the plate boundary between Europe and Iberia. It coincides with an important Moho jump: the crust is about $50 \mathrm{~km}$ thick beneath the PAZ in Central Pyrenees and about $30 \mathrm{~km}$ thick beneath the NPZ [Gallart et al., 1981; Daignières et al., 1982; Choukroune et al., 1990]. The opening of the Bay of Biscay was responsible for the creation of pull-apart basins along the NPF that generated a narrow zone of high temperature - low pressure metamorphism [e.g., Goldberg and Leyreloup, 1990], and for the lherzolite emplacement in the NPZ sediments during mid Cretaceous [Vielzeuf and Kornprobst, 1984].

\section{Data and results}

We installed seven broadband three component seismic stations from the French LITHOSCOPE program (see location 
Table 1: Station locations

\begin{tabular}{cccccc}
\hline Station & Lat. $\left({ }^{\circ}\right)$ & Long. $\left({ }^{\circ}\right)$ & Station & Lat. $\left({ }^{\circ}\right)$ & Long. $\left(^{\circ}\right)$ \\
\hline AUC & 43.66 & 0.56 & MLS & 42.96 & 1.09 \\
LTE & 43.18 & 0.76 & VIH & 42.63 & 0.77 \\
MRT & 42.92 & 0.75 & PON & 42.40 & 0.76 \\
BDB & 43.06 & 0.15 & AVL & 41.88 & 0.75 \\
\hline
\end{tabular}

Table 1) on a $200 \mathrm{~km}$ long profile normal to the trend of the Pyrenees, from Auch in southern France to Lerida in northern Spain (Fig. 1). These stations, recording in triggered mode, were set up during a three month period (February to April, 1993). We installed three more experimental stations with continuous recording at BDB, MLS and LTE during a supplementary period (August to October 1993). We also digitized SKS and SKKS phases from analog data recorded at the station MLS during the period 1975-1979.

We measured shear wave splitting using the algorithm of Silver and Chan [1991]. For the events located at distances less than $100^{\circ}$, we generally performed the measurements on SKS and SKKS phases simultaneously (see Table 2). At larger epicentral distances, we made independent measurements on each seismic phase when the signal was clear enough. Fig. 2 shows three examples of data, one at the southernmost station (AVL), and the others at stations of the NPZ (BDB and MLS). The anisotropy at each station is characterized by the azimuth $\phi$ of the fast split shear wave with respect to the north, and $\delta \mathrm{t}$, the time delay between the fast and slow phases (see Table 2). A 'null direction' means either that the initial polarization of the shear wave was parallel to the fast or slow directions in the anisotropic layer, or that there is no anisotropy beneath the station. If only one 'null' result is available, as at MRT, it is impossible to discriminate between these alternatives.

Between February and April 1993, only one good event (93 038) has been suitable for anisotropy measurements. Results for this event are well constrained for the southernmost stations (VIH, PON and AVL) whereas the same event gives only a

Table 2: Events used and splitting parameters

\begin{tabular}{|c|c|c|c|c|c|c|c|c|c|}
\hline Station & $\begin{array}{l}\text { Event } \\
\text { (yr/day) }\end{array}$ & $\begin{array}{c}\text { Dist } \\
\left({ }^{\circ}\right)\end{array}$ & $\begin{array}{c}\text { Baz. } \\
\left({ }^{\circ}\right)\end{array}$ & Phase & $\begin{array}{l}\phi \\
\left({ }^{\circ}\right)\end{array}$ & $\begin{array}{l}\sigma_{\phi} \\
\left({ }^{\circ}\right)\end{array}$ & $\begin{array}{l}\delta \mathrm{t} \\
(\mathrm{s})\end{array}$ & $\begin{array}{l}\sigma_{\delta \mathrm{t}} \\
(\mathrm{s})\end{array}$ & $\begin{array}{l}\text { Record } \\
\text { quality }\end{array}$ \\
\hline$\underset{n}{\mathrm{AUC}}$ & $\begin{array}{l}93038 \\
93108 a\end{array}$ & 90 & $\begin{array}{l}33 \\
59\end{array}$ & $\begin{array}{c}\text { SKS }+ \text { SKKS } \\
\text { SKS }\end{array}$ & 46 & 10 & 1.2 & 0.4 & poor \\
\hline LTE & $93108 b$ & 149 & 234 & SKS & null & & & & poor \\
\hline & 93284 & 95 & 36 & SKS & 98 & 17 & 0.6 & 0.2 & good \\
\hline MRT & 93116 & 92 & 30 & SKS+SKKS & null & & & & good \\
\hline $\mathrm{BDB}$ & 93061 & 150 & 10 & SKS & null & & & & poor \\
\hline & 93249 & 135 & 40 & SKS & 60 & 13 & 1.2 & 0.6 & poor \\
\hline " & 93249 & 135 & 40 & SKKS & 100 & 8 & 1.2 & 0.3 & good \\
\hline " & 93284 & 96 & 35 & SKS+SKKS & 96 & 19 & 0.5 & 0.3 & good* \\
\hline n & 93292 & 89 & 237 & SKS+SKKS & 92 & $>22$ & 0.8 & 2.4 & fair \\
\hline 'mean' & & & & & 90 & 10 & 0.8 & 0.2 & \\
\hline MLS & 75072 & 157 & 26 & SKKS & 64 & 9 & 1.0 & 0.2 & good* \\
\hline & 75222 & 90 & 239 & SKS & 94 & 14 & 0.9 & 0.2 & good \\
\hline " & 79047 & 90 & 247 & SKS+SKKS & 41 & $>22$ & 2.4 & 1.7 & poor \\
\hline & 93249 & 135 & 41 & SKKS & 78 & 6 & 1.0 & 0.2 & good \\
\hline & 93249 & 135 & 41 & SKS & 69 & $>22$ & 0.6 & 2.3 & poor \\
\hline$"$ & 93284 & 96 & 36 & SKS & 83 & 7 & 1.0 & 0.2 & good \\
\hline 'mean' & & & & & 70 & 10 & 0.9 & 0.2 & \\
\hline VIH & 93038 & 91 & 33 & SKS+SKKS & 102 & 6 & 1.3 & 0.2 & good \\
\hline PON & 93038 & 91 & 33 & SKS+SKKS & 99 & 2 & 1.5 & 0.1 & good \\
\hline AVL & 93038 & 91 & 33 & SKS+SKKS & 100 & 5 & 1.5 & 0.3 & good \\
\hline & 93038 & 91 & 33 & SKKS & 102 & 3 & 1.3 & 0.2 & good* \\
\hline
\end{tabular}

* measurements shown in Fig. 2 poorly constrained result at AUC. Unfortunately, this event did not trigger at BDB, LTE and MRT. Several measurements were nevertheless performed at BDB and MLS from events that occurred during the August-October period. Results at LTE appear to be inconsistent. The null direction found for event 93108 is not compatible with the fast direction given by the other event but the poor quality of this record may explain the discrepancy. By contrast, results at BDB and MLS are coherent when error bars are taken into account. For these two stations, a 'mean' value is determined. This value is not an arithmetic mean: from the $95 \%$ confidence interval of each measurement in the $\phi$ $\delta$ domain (see Fig. 2), we define a common area from which the most probable result (called 'mean' in Table 2) is determined.

The anisotropy parameters (Fig. 1) define two groups of data. The first group, the three southern stations located on the Ibcrian plate, is characterized by homogeneous results. They display large $\delta \mathrm{t}$ (about 1.3-1.5 s) and uniform $\phi$ directions (around N100). The second group, the five northern stations located on the European plate, displays less homogeneous results, with smaller $\delta t(\leq 1 \mathrm{~s})$ and a variability in $\phi$. The two stations located in the NPZ (BDB and MLS) display nearly similar $\delta$ (respectively 0.8 and $0.9 \mathrm{~s}$ ), but slightly different $\phi\left(90\right.$ and $70^{\circ}$ respectively). At MRT, we only found a 'null direction'. This confirms the variability of anisotropy parameters in this area: If the null direction signifies an absence of anisotropy (i.e., $\delta \mathrm{t}=0$ ), the $\delta \mathrm{t}$ displays strong variations across the belt. On the other hand, if the 'null direction' corresponds to the fast and slow directions in an anisotropic structure, it implies a strong variability of $\phi$. However, the result at MRT precludes any interpretation of possible splitting beneath the NPF, as observed at NE10 (Fig. 1) by Souriau and Njike-Kassala [1993].

\section{Discussion and conclusions}

The data collected during this test experiment are limited in number and quality. This is due to the short time deployment of the array, but also to the small number of triggers at some stations. Continuous recording as in the fall 1993 experiment partly solved this problem. The few measurements do not allow us to investigate azimuthal dependence of the results but their coherency, in particular for the Iberian stations, lead us to discuss hypotheses about the location and the origin of the splitting.

\section{Lithospheric or asthenospheric anisotropy?}

If the anisotropy was controlled by the large scale asthenospheric flow related to the present-day absolute plate motion (APM), we would expect approximately the same directions and amplitudes of the anisotropy for the two plates. Our observations suggest it is not the case. By contrast, we argue that an important component of the anisotropy could be in the lithosphere. This is suggested by the variability of the anisotropy at a small scale ( $\phi$ and $\delta$ t display notable variations in tens of kilometers) and by the relation to the surface geology (each group of measurements is associated with a different plate). To illustrate these variations, we plot on Fig. 3 the values of $\delta t$ and $\phi$ along the $\mathrm{N}-\mathrm{S}$ profile, with a possible geometry of the system which is supported by P-wave residual studies [Poupinet et al., 1992].

The NPF, which represents the boundary between the two plates, also defines the boundary between the two groups of results. If the anisotropy was uniformly distributed in the lithosphere, a 2.5 to $3.5 \%$ anisotropy could explain the 0.3 to 0.5 $\mathrm{s} \delta \mathrm{t}$ variation across the NPF. Such an anisotropy is compatible with petrophysical results [e.g., Mainprice and Silver, 1993]. 

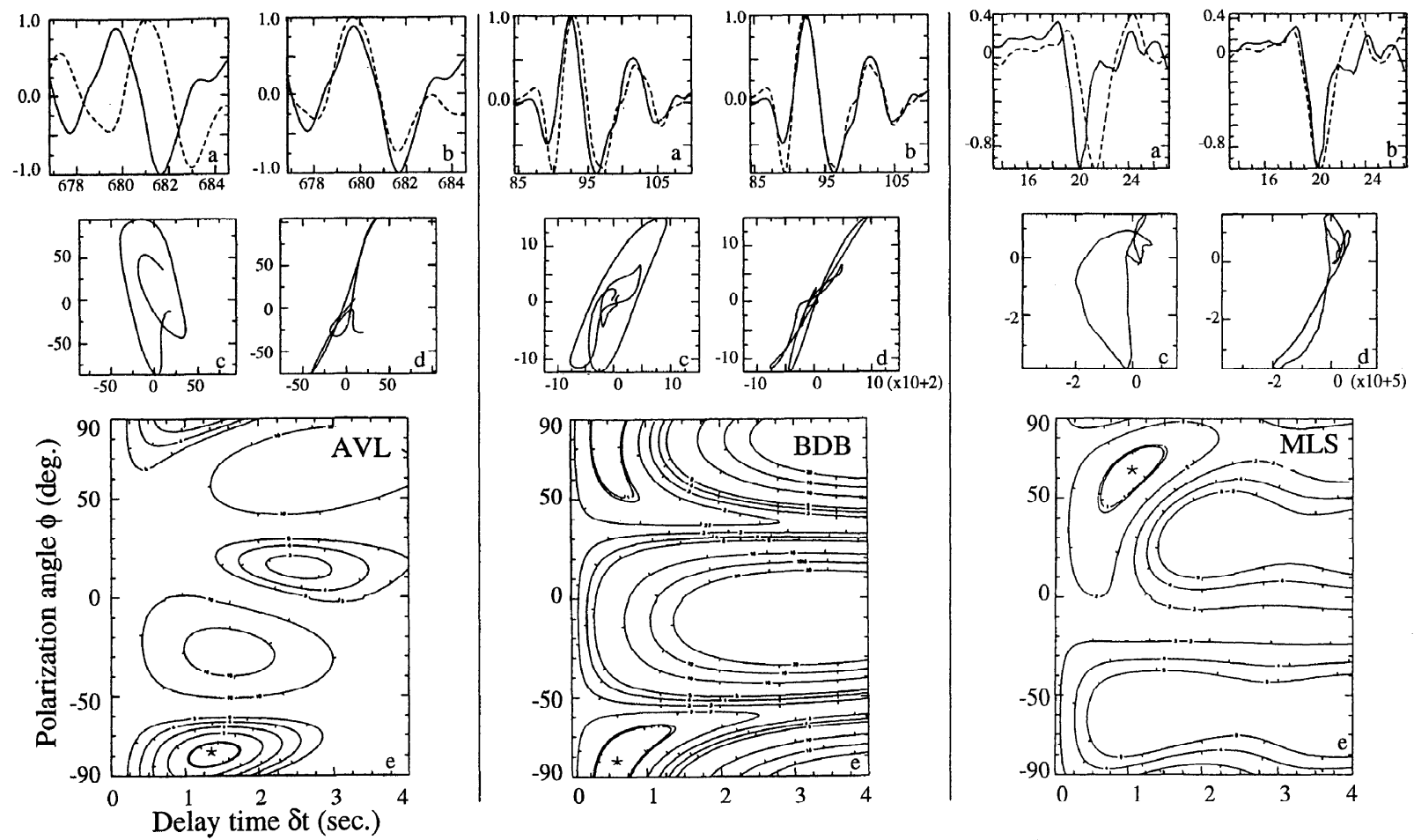

Figure 2: Example of splitting measurements : SKKS phase of event 93038 at AVL (left), SKS+SKKS phases of event 93284 at BDB (middle) and digitized SKKS phase of event 75072 at MLS (right). Top: overplot of the fast (solid) and slow (dashed) components of the split shear waves, uncorrected (a) and corrected (b) for the lag time. The particle motions in the horizontal plane are shown below, also uncorrected (c) and corrected (d). Bottom (e): contour plot of energy on the transverse component as a function of the delay time $\delta \mathrm{t}$ (seconds) and the polarization angle $\phi$ (degrees) of the fast split shear wave. Double contours represent the $95 \%$ confidence interval.
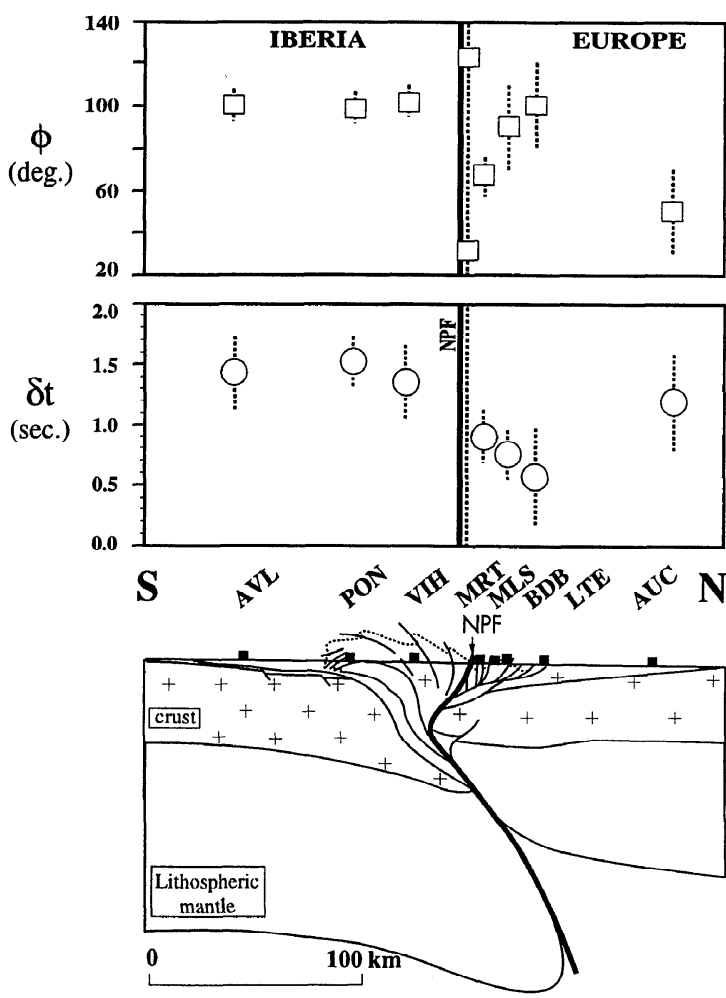

Figure 3: Schematic N-S section across a lithospheric model of the Pyrenees, adapted from Mattauer [1990] and Choukroune [1992]. The measured delay times $\delta t$ and the orientations of the fast split shear waves $\phi$, with their error bars are plotted above. Results at MRT give unconstrained $\delta \mathrm{t}$.
However, with SKS splitting alone, no constraint may be obtained on the depth range where anisotropy is located.

\section{Possible origins of the anisotropy}

-European margin: Geophysical and geological observations indicate the former European margin was strongly thinned prior the Pyrenean compression. The lherzolite massifs of the NPZ display evidence for olivine plastic deformation occurring at temperature of about $1200^{\circ} \mathrm{C}$ and depth of $50 \mathrm{~km}$ [Fabriès et al., 1991]. If the base of the lithosphere is defined by the 1100 or $1200^{\circ} \mathrm{C}$ isotherm, this suggests that at mid-Cretaceous times, the lithosphere beneath the NPZ was thinned and almost reduced to its crustal part. In these conditions, the former mantle fabric could have been erased and the present anisotropy could correspond to a Pyrenean deformation. By contrast, there is no evidence indicating the Iberian plate suffered the same thermal event.

- Iberian plate: Several studies were carried out to investigate the Iberian upper mantle anisotropy. SKS splitting has been obtained at two stations located on Hercynian structures in central Spain [Vinnik et al., 1989; Silver and Chan, 1991]. They give a roughly E-W fast axis, parallel to the Hercynian crustal fabric. From deep seismic soundings (DSS) in SW Iberia, Diaz et al. [1993] found evidences for the existence of three anisotropic layers in the lithosphere with fast axes ranging from $\mathrm{N} 12^{\circ} \mathrm{E}$ to $\mathrm{N} 38^{\circ} \mathrm{E}$. They invoked the NS horizontal stress related to the present day compression of Africa and Eurasia. Using surface waves, Maupin and Cara [1990] compared Ralcigh and Love wave data for retrieving a possible azimuthal anisotropy. Data were available only in the SW corner of the Iberian peninsula. Their data require the presence of anisotropy below $100 \mathrm{~km}$ 
depth, with horizontal S-velocities about $8 \%$ faster than vertical velocities at $140 \mathrm{~km}$ depth. However, due to a high noise level, the azimuthal velocity variations related to anisotropy could not be retrieved. The apparent inconsistency of SKS splitting with DSS and surface wave anisotropy suggests either lateral variations of the mantle structure between the different investigated areas or variations with depth of the anisotropic properties of the mantle.

One way to explain the Iberian anisotropy in the Pyrenees is to relate it to the displacement of the Iberian plate with respect to Europe at Cretaceous times. The rotation of Iberia could have induced a mantle deformation as a horizontal shearing at the base of the lithospherc and/or in the asthenosphere. The arguments in favor of this interpretation are that the $\phi$ are oriented parallel to the strike of the NPF and that the $\delta$ t display constant values at the Iberian stations. This interpretation nevertheless requires either that the asthenospheric deformation has been preserved since Cretaccous in the upper mantle or, alternatively, that the $400 \mathrm{~km}$ strike slip motion of Iberia has induced a pervasive deformation through the whole Iberian lithospheric mantle.

A second way to explain the Iberian anisotropy is to relate it to a pre-existing lithospheric structure. During the Pyrenean orogeny, the total N-S shortening remained small, on the order of $50-100 \mathrm{~km}$ [Choukroune, 1992] and the interpretations of the ECORS profile proposed by Choukroune et al. [1990] or by Mattauer [1990] do not imply a pervasive deformation of the Iberian lithospheric mantle. By contrast, most of the pervasive structures in the Axial Zone are Hercynian and oriented parallel to the belt. The reconstruction of the Variscan belt [Matte, 1991] displays similar orientations of the Hercynian structures between central Spain and the Pyrenees. This leads us to suggest that the roughly E-W fast directions found both south of the NPF and at Toledo may be inherited from a Hercynian lithosphcric structure.

Some possible interpretations are proposed to explain the characteristics of the anisotropy measured on the two plates. The scattered values obtained north of the NPF suggest they may be related to the lithospheric deformation of this zone during the Pyrenean orogeny. To explain the strong E-W oriented anisotropy in the Iberian plate, both lithospheric and asthenospheric sources may be invoked. Moreover, contributions due to several orogenies may be superimposed : the large strike-slip motion of Iberia may have generated a strong anisotropy but a contribution may also be inherited from the Hercynian orogeny. Because an E$\mathrm{W}$ fast direction is predicted by the various possible explanations, it is presently impossible to discriminate their different contributions without additional data.

Acknowledgements. We thank the colleagues who hclped us for data processing and field work, particularly M. Vadell, G. Ceuleneer, A. Vauchez, P. Roudil and M. Martel. We are also grateful to our Catalan colleagues R. Font and C. Olivera. Helpful reviews were provided by $L$. Vinnik, P. Choukroune and an anonymous reviewer. The manuscript also benefited from discussions with J.L. Bouchez, A. Vauchez, R. Russo and P. Silver. This study has been supported by AA Tomographie, INSU, 1993 and has been partly made at the Carnegie Institution of Washington (DTM/GL).

\section{References}

Choukroune P., Tectonic evolution of the Pyrenees, Annu. Rev. Earth Planet. Sci., 20, 143-158, 1992.

Choukroune P., f. Roure, B. Pinet and ECORS-Pyrenees-Team, Main results of the ECORS Pyrenees profile, Tectonophysics, 173, 411-423, 1990.

Daignières M., J. Gallart, E. Banda and A. Hirn, Implication of the seismic structure for the orogenic evolution of the Pyrenees range, Earth Planet. Sci. Lett. , 57, 88-110, 1982.

Diaz J., A. Hirn, J. Gallart and L. Senos, Evidence for azimuthal anisotropy in southwest Iberia from deep seismic sounding, Phys. Earth Planet. Int. , 78, 193-206, 1993.

Fabriès J., J. P. Lorand, J. L. Bodinier and C. Dupuy, Evolution of upper mantle beneath Pyrenees: evidences from orogenic spinel lherzolite massifs, J. Petrol, Special issue "Orogenic Lherzolites and Mantle Processes", 55-76, 1991.

Gallart J., E. Banda and M. Daignières, Crustal structure of the Paleozoic Axial Zone of the Pyrenees and the transition of the North Pyrenean Zone, Ann. Geophys., 37, 457-480, 1981.

Goldberg J. M. and A. f. Leyreloup, High temperature-low pressure Cretaceous metamorphism related to crustal thinning (Eastern North Pyrenean Zone, France), Contr. Miner. Petrol., 104, 194-207, 1990.

Mainprice D. and P. G. Silver, An evaluation of the factors affecting shear wave splitting in the mantle from petrofabric measurements of mantle xenoliths, Phys. Earth Planet. Int. , 78, 257-280, 1993.

Mattauer M., Une autre interprétation du profil ECORS Pyrénées, Bull. Soc. géol. France, (8), VI, 307-311, 1990.

Matte P., Accretionary history and crustal evolution of the Variscan belt in western Europe, Tectonophysics, 196, 309-337, 1991.

Maupin V. and M. Cara, Love-Rayleigh wave incompatibility and possible deep upper mantle anisotropy in the Iberian peninsula, Pure Appl. Geophys., 138, 429-444, 1990.

Nicolas A. and N. I. Christensen, Formation of anisotropy in upper mantle peridotites - A review, in Composition, structure and dynamics of the lithosphere-asthenosphere system, Fuchs, K. and C. Froidevaux ed., Am. Geophys. Un., Washington, D.C., 111-123, 1987.

Poupinet G., A. Souriau, M. Vadell and J. D. Njike-Kassala, Constraints on the lithospheric structure beneath the North Pyrenean Fault from teleseismic observations, Geology, 20, 157-160, 1992.

Silver P. G. and W. W. Chan, Implications for continental structure and evolution from seismic anisotropy, Nature, 335, 34-39, 1988.

Silver P. G. and W. W. Chan, Shear wave splitting and subcontinental mantle deformation, J. Geophys. Res., 96, 16429-16454, 1991.

Souriau A. and J. D. Njike-Kassala, Anisotropy beneath the North Pyrenean Fault, Phys. Earth Planet. Int., 78, 239-244, 1993.

Vielzeuf D. and J. Kornprobst, Crustal splitting and the emplacement of the Pyrenean lherzolites and granulites, Earth Planet. Sci. Lett. , 67, 87 96, 1984 .

Vinnik L. P., V. Farra and B. Romanovicz, Azimuthal anisotropy in the earth from observations of SKS at GEOSCOPE and NARS broadband stations, Bull. seism. Soc. Am. , 79, 1542-1558, 1989.

G.B.: Laboratoire de Tectonophysique, Univ. Montpellier II, 34095

Montpellier cedex 5, France. Email: barruol@dstu.univ-montp2.fr A.S.: OMP / GRGS, 14 av Belin, 31400 Toulouse, France. Email: souriau@pontos.cnes.fr

(Received: March 3, 1994; Revised: July 5, 1994; accepted, September 29, 1994.) 